\title{
A predictive kinetic model for inhibitory effect of nitrite on myeloperoxidase catalytic activity towards oxidation of chloride
}

\author{
Yahya R. Tahboub ${ }^{1,2^{*}}$, Mohammad M. Fares ${ }^{1}$ \\ ${ }^{1}$ Department of Applied Chemistry, Faculty of Science \& Arts, Jordan University of Science and Technology, Irbid, Jordan; \\ ${ }^{2}$ Department of Applied Chemistry, Faculty of Applied Sciences, Taibah University, Almadinah Almonawwarah, Saudi Arabia; \\ *Corresponding Author: tahboub@just.edu.jo
}

Received 13 April 2011; revised 19 May 2011; accepted 2 June 2011.

\section{ABSTRACT}

Myeloperoxidase (MPO) is a neutrophil enzyme that employs hydrogen peroxide $\left(\mathrm{H}_{2} \mathrm{O}_{2}\right)$ to catalyze the oxidation of chloride $\left(\mathrm{Cl}^{-}\right)$to hypochlorous acid (HOCl). Accepted mechanism is based on rapid reaction of native MPO with $\mathrm{H}_{2} \mathrm{O}_{2}$ to produce Compound I (MPO-I) which oxidizes $\mathrm{Cl}^{-}$through a $2 \mathrm{e}^{-}$transition generating MPO and HOCl. MPO-I also reacts with $\mathrm{H}_{2} \mathrm{O}_{2}$ to generate Compound II (MPO-II) which is inactive in 2e oxidation of $\mathrm{Cl}^{-}$. Nitrite $\left(\mathrm{NO}_{2}^{-}\right)$inhibits the $2 \mathrm{e}$ oxidation of $\mathrm{Cl}^{-}$by reaction with MPO-I through 1e transition generating MPO-II and nitrite radical. $\mathrm{H}_{2} \mathrm{O}_{2}$ consumption during steadystate catalysis was monitored amperometrically by a carbon fiber based $\mathrm{H}_{2} \mathrm{O}_{2}$-biosensor at $25^{\circ} \mathrm{C}$. Results demonstrated that in absence of $\mathrm{NO}_{2}^{-}$ reactions were monophasic and rapid (complete $\mathrm{H}_{2} \mathrm{O}_{2}$ consumption occurs in $<10 \mathrm{~s}$ ). As concentration of $\mathrm{NO}_{2}^{-}$increases, reactions change to biphasic (rapid step followed by a slow step) and both steps have been inhibited by $\mathrm{NO}_{2}^{-}$. A predictive kinetic model describing the inhibittory effect of $\mathrm{NO}_{2}^{-}$was developed and applied to experimental results. The model is based on the assumption that MPO-I cannot be detected during steady-state catalysis. Calculated rate constants are in agreement with those obtained from pre-steady state kinetic methods.

Keywords: MPO-Hydrogen Peroxide-Chloride

System; Nitrite Inhibitor; $\frac{k_{4}}{k_{3}}, \frac{k_{4}}{k_{2}}$, and $\frac{k_{2}}{k_{3}}$ Ratios;

Theoretical Kinetic Model

\section{INTRODUCTION}

Myeloperoxidase (MPO) is a human peroxidase enzyme and a lysosomal protein stored in azurophilic granules of the neutrophil. Its deficiency can severely cause quantitative or functional genetic disorder [1]. The major role of MPO is to aid in microbial killing. It oxidizes tyrosine to tyrosyl radical using hydrogen peroxide as oxidizing agent [2]. Furthermore, the MPO catalyzed production of $\mathrm{HOCl}$ from hydrogen peroxide $\left(\mathrm{H}_{2} \mathrm{O}_{2}\right)$ and chloride ion $\left(\mathrm{Cl}^{-}\right)$, together with tyrosyl radical, are aimed at killing bacteria and other pathogens. The MPO-hydrogen peroxide-chloride system has been considered an important pathophysiologic factor in kidney disease [3], to enhance lipid oxidation in LDL in presence of $\mathrm{SCN}^{-}$catalyst [4], to lead to oxidative damage of apolipoprotein A-I [5], to oxidizes free $\alpha$-amino acids to aldehydes [6], leading to advanced glycation products present in human lesion material [7].

Vast range of inflammatory diseases was found to be correlated with products of MPO nitration of tyrosine residues. Myeloperoxidase can oxidize nitrite ions to an intermediate capable of nitrating tyrosine and tyrosyl residues in proteins [8-10].

The simplified mechanism that governs the catalytic activity of MPO can be represented by the classic peroxidases catalytic cycle as follows:

Chloride oxidation starts by rapid reaction of ground state MPO with $\mathrm{H}_{2} \mathrm{O}_{2}$ to form Compound I (MPO-I). Compound I is capable of oxidizing chloride $\left(\mathrm{Cl}^{-}\right)$ through a $2 \mathrm{e}^{-}$transition generating the ground state MPO and hypochlorous acid ( $\mathrm{HOCl})$. During turnover, some MPO-I is converted to Compound (II) (MPO-II) by reaction with $1 \mathrm{e}^{-}$donors such as nitrite $\left(\mathrm{NO}_{2}^{-}\right)$or $\left(\mathrm{H}_{2} \mathrm{O}_{2}\right)$. As could be seen in equations 1 to $4[11,12,17]$.

$$
\mathrm{MPO}+\mathrm{H}_{2} \mathrm{O}_{2} \stackrel{k_{1}}{\longrightarrow} \mathrm{MPO}-\mathrm{I}+\mathrm{H}_{2} \mathrm{O}
$$




$$
\begin{gathered}
\mathrm{MPO}-\mathrm{I}+\mathrm{Cl}^{-}+\mathrm{H}^{+} \stackrel{k_{2}}{\longrightarrow} \mathrm{MPO}+\mathrm{HOCl} \\
\mathrm{MPO}-\mathrm{I}+\mathrm{NO}_{2}^{-} \stackrel{k_{3}}{\longrightarrow} \mathrm{MPO}-\mathrm{II}+\mathrm{NO}_{2} \\
\mathrm{MPO}-\mathrm{I}+\mathrm{H}_{2} \mathrm{O}_{2} \stackrel{k_{4}}{\longrightarrow} \mathrm{MPO}-\mathrm{II}+\mathrm{H}_{2} \mathrm{O}_{2}
\end{gathered}
$$

MPO-II is believed to be inactive in chloride oxidation. The decay of MPO-II to ground state is considered as the rate-limiting step during steady-state catalysis $[11,12]$.

Pre-steady-state and steady-state studies based on stopped-flow mixing and optical detection were employed for studies of MPO-hydrogen peroxide-chloride system in presence and absence of nitrite [13,14]. In such studies, larger than physiological plasma concentrations of MPO and/or $\mathrm{NO}_{2}^{-}$were employed to monitor measurable changes in absorbance at selected wavelengths. Steady-state methods with amperometric monitoring have advantages over optical methods. In such methods, the oxidation or reduction of a targeted reactant or product is directly monitored at the surface of a selective electrochemical biosensor. However, lack of biosensors with enough sensitivity, selectivity and short response time limited their role to initial rate measurements [13-17].

Recently, combination $\mathrm{H}_{2} \mathrm{O}_{2}$-biosensors with adequate sensitivity $(2 \mathrm{pA} / \mathrm{nM})$ and a relatively short response time $(<2 \mathrm{~s})$ were developed [18-20].

In a previous study [20], we employed a carbon fiber based $\mathrm{H}_{2} \mathrm{O}_{2}$-biosensor to study the effect of $\mathrm{NO}_{2}^{-}$on catalytic activity of MPO towards oxidation of chloride under respective physiological concentrations. Our results confirmed the inhibitory nature of $\mathrm{NO}_{2}^{-}$. In this study, we utilized experimental data to develop a kinetic model capable of explaining the monophasic and biphasic phenomena. Additionally, $\frac{k_{4}}{k_{3}}, \frac{k_{4}}{k_{2}}$, and $\frac{k_{2}}{k_{3}}$ ratios were estimated and the dependence of $k_{1}$ on $\left[\mathrm{Cl}^{-}\right]$ and $\left[\mathrm{NO}_{2}^{-}\right]$was determined.

\section{EXPERIMENTAL}

\subsection{Reagents}

Chemicals used for preparation of buffer, stock and standard solutions were of analytical grade reagents and purchased from Sigma Chemical Co. (St. Louis, MO, USA). Phosphate buffer, $100 \mathrm{mM}$ and $\mathrm{pH}$ 7.00, was prepared by mixing appropriate volumes of $0.10 \mathrm{M}$ $\mathrm{NaH}_{2} \mathrm{PO}_{4}$ and $0.10 \mathrm{M} \mathrm{Na}_{2} \mathrm{HPO}_{4}$ to achieve $\mathrm{pH}$ 7.00. A $3.00 \mathrm{mM} \mathrm{H}_{2} \mathrm{O}_{2}$ solution was freshly prepared from stock solutions prepared by sequential dilutions from $30 \%$ $\mathrm{H}_{2} \mathrm{O}_{2}$ solution. Standard solutions of chlorides and $\mathrm{NO}_{2}^{-}$ were prepared by sequential dilutions from their respec- tive sodium salts. All solutions were bubbled with high purity $\mathrm{N}_{2}$ gas before use. MPO was purified from human leukocytes [21-23]. A $30 \mu \mathrm{M}$ MPO solution was freshly prepared by diluting measured amounts with buffer.

\subsection{Electrochemical Measurements}

The Amperometric system consisted from an Apollo 4000 free radical analyzer, ISO-HPO-100 $\mathrm{H}_{2} \mathrm{O}_{2}$-biosensor and a thermostated measurement chamber (WPI, Sarasota, FL, USA). All experiments were performed at room temperature.

For each experiment, $3.00 \mathrm{~mL}$ of $100 \mathrm{mM}$ phosphate buffer solution containing $30 \mu \mathrm{M}$ EDTA were placed in the measurement chamber. For effect of nitrite measurements, a $100 \mathrm{mM} \mathrm{Cl}^{-}$and varied concentrations of $\mathrm{NO}_{2}^{-}(0$ - 100) $\mu \mathrm{M}$ were pre-incubated with buffer solution in the chamber. For effect of chloride measurements, a $100 \mu \mathrm{M} \mathrm{NO} \mathrm{NO}_{2}^{-}$and varied concentrations of $\mathrm{Cl}^{-}(0-$ 100) $\mathrm{mM}$ were pre-incubated with buffer solution in the chamber. The electrode was immersed and magnetic stirrer was turned on at fixed moderate speed. Continuous amperometric monitoring started after addition of 30 $\mu \mathrm{L} \mathrm{H}_{2} \mathrm{O}_{2}(10 \mu \mathrm{M})$. Reactions started with addition of 5.0 $\mu \mathrm{L}$ MPO solution $(50 \mathrm{nM})$ and allowed to proceed until complete decay of initial current signal. $\mathrm{H}_{2} \mathrm{O}_{2}$ concentrations $(\mu \mathrm{M})$ versus time (s) plots were obtained by setting the initial current signal to $10 \mu \mathrm{M} \mathrm{H}_{2} \mathrm{O}_{2}$ [19-20].

\section{RESULTS AND DISCUSSION}

Due to its much higher concentration (100 - $140 \mathrm{mM})$ relative to other halides, chloride is assumed to be the physiological substrate for MPO. Time course $\mathrm{H}_{2} \mathrm{O}_{2}$ decay plots for MPO-catalyzed oxidation of $\mathrm{Cl}^{-}$, at a selected normal plasma level $(100 \mathrm{mM})$, in presence of increasing $\mathrm{NO}_{2}^{-}$concentrations were studied by continuous amperometric monitoring of $\mathrm{H}_{2} \mathrm{O}_{2}$ consumption (Figure 1) [20]. A monophasic plot prevails in absence of $\mathrm{NO}_{2}^{-}$(Figure 1(a)) which is demonstrated by a rapid consumption of $\mathrm{H}_{2} \mathrm{O}_{2}$. As $\mathrm{NO}_{2}^{-}$concentration increases, plots became biphasic and the rapid step is followed by a slower second step which is observed as an exponential decay of $\mathrm{H}_{2} \mathrm{O}_{2}$ signal (Figures 1(b)-(d)). The second step dominates at larger $\mathrm{NO}_{2}^{-}$concentration (Figure 1(d)).

Further prevailing of second phase was observed, when $\mathrm{Cl}^{-}$was decreased in presence of $100 \mu \mathrm{M} \mathrm{NO}-$ (Figure 2). Both steps are observed in Figure 2(e) which is actually Figure 1(d). As $\mathrm{Cl}^{-}$concentration continues to decrease, the second step is further extended and first step is disappeared. (Figures 2 (a)-(c)). Extension of second step is accompanied by increase in reaction time. 


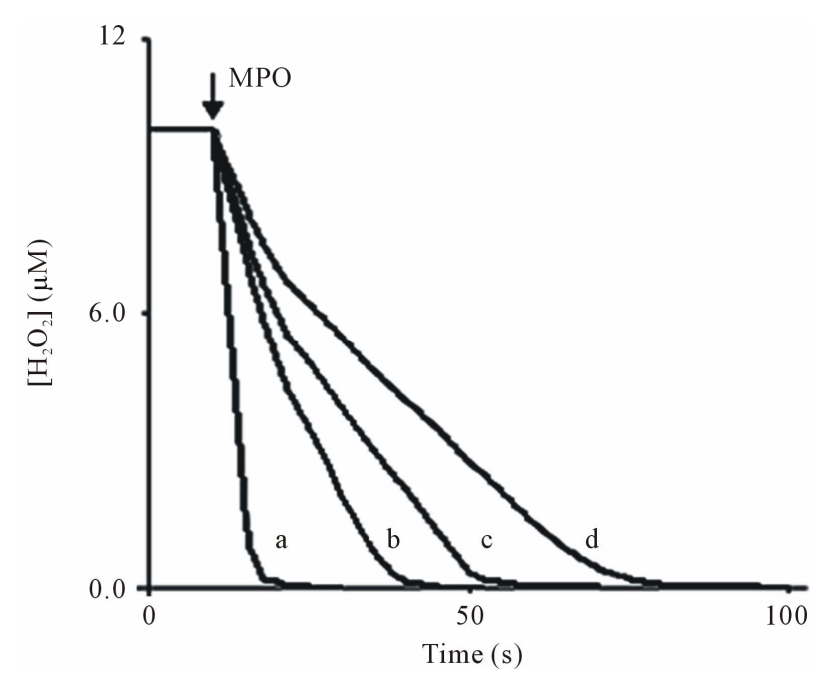

Figure 1. Effect of $\mathrm{NO}_{2}^{-}$on MPO-catalytic activity towards oxidation of $\mathrm{Cl}^{-}$(Courtesy of portugaliae electrochimica acta with permission). $\mathrm{H}_{2} \mathrm{O}_{2}$ consumption plots as a function of $\left[\mathrm{NO}_{2}^{-}\right.$]. Reactions were started by the addition of $50 \mathrm{nM} \mathrm{MPO}$ to $10 \mu \mathrm{M} \mathrm{H}_{2} \mathrm{O}_{2}$ in $100 \mathrm{mM}$ phosphate buffer, $\mathrm{pH}$ 7.0, containing $30 \mu \mathrm{M}$ EDTA pre-incubated with $100 \mathrm{mM} \mathrm{Cl}^{-}$(a) and 25 (b), 50 (c), $100 \mu \mathrm{M} \mathrm{NO} \mathrm{NO}_{2}^{-}$(d). Reactions were carried at $25^{\circ} \mathrm{C}$. Plots are average of four replicates.

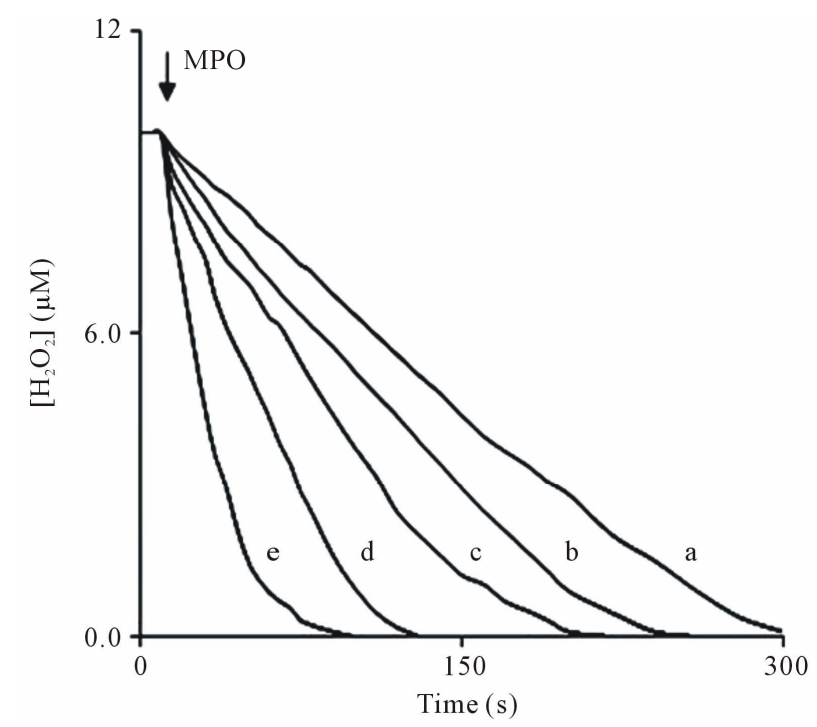

Figure 2. Effect of $\mathrm{Cl}^{-}$on MPO-catalytic activity towards oxidation of $\mathrm{Cl}^{-}$in presence of $\mathrm{NO}_{2}^{-} \cdot \mathrm{H}_{2} \mathrm{O}_{2}$ consumption plots as a function of $\left[\mathrm{Cl}^{-}\right]$. Reactions were started by the addition of 50 nM MPO to $10 \mu \mathrm{M} \mathrm{H}_{2} \mathrm{O}_{2}$ in $100 \mathrm{mM}$ phosphate buffer, $\mathrm{pH} 7.0$, containing $30 \mu \mathrm{M}$ EDTA, pre-incubated with $100 \mu \mathrm{M} \mathrm{NO}_{2}^{-}$ and 5 (a), 10 (b), 25 (c), 50 (d) and100 $\mathrm{mM} \mathrm{Cl}^{-}$(e) Reactions were carried at $25^{\circ} \mathrm{C}$. Plots are average of four replicates.

\subsection{Proposed Kinetic Model}

Referring to mechanism in introduction, reaction 1 is known to be very fast, $k_{1}$ is in the order of $10^{7}$ [24], whereas reaction 2 is slower with $k_{2} \sim 10^{4}$ [25]. Interestingly, reaction 3 is found to be extremely fast, $k_{3}$ in the order of $10^{7}$ [13] and $k_{4}\left(10^{2}-10^{4}\right)$ consequently much slower than $k_{1}[17,26-28]$.

Let rate of consumption of $\mathrm{H}_{2} \mathrm{O}_{2}$ be written as:

$$
-\frac{\mathrm{d}\left[\mathrm{H}_{2} \mathrm{O}_{2}\right]}{\mathrm{d} t}=k_{1}[\mathrm{MPO}]\left[\mathrm{H}_{2} \mathrm{O}_{2}\right]+k_{4}[\mathrm{MPO}-\mathrm{I}]\left[\mathrm{H}_{2} \mathrm{O}_{2}\right]
$$

On Parallel, the rate of consumptions of MPO, $\mathrm{Cl}^{-}$, and $\mathrm{NO}_{2}^{-}$ions together with rate of formation of $\mathrm{HOCl}$ can be written as:

$$
\begin{gathered}
-\frac{\mathrm{d}\left[\mathrm{Cl}^{-}\right]}{\mathrm{d} t}=\frac{\mathrm{d}[\mathrm{HOCl}]}{\mathrm{d} t}=k_{2}[\mathrm{MPO}-\mathrm{I}]\left[\mathrm{Cl}^{-}\right] \\
-\frac{\mathrm{d}[\mathrm{MPO}]}{\mathrm{d} t}=k_{1}[\mathrm{MPO}]\left[\mathrm{H}_{2} \mathrm{O}_{2}\right]-k_{2}[\mathrm{MPO}-\mathrm{I}]\left[\mathrm{Cl}^{-}\right] \\
-\frac{\mathrm{d}\left[\mathrm{NO}_{2}^{-}\right]}{\mathrm{d} t}=k_{3}[\mathrm{MPO}-\mathrm{I}]\left[\mathrm{NO}_{2}^{-}\right]
\end{gathered}
$$

Furthermore the rate of formation of MPO-II is:

$$
\begin{aligned}
\frac{\mathrm{d}[\mathrm{MPO}-\mathrm{II}]}{\mathrm{d} t}= & k_{3}[\mathrm{MPO}-\mathrm{I}]\left[\mathrm{NO}_{2}^{-}\right] \\
& +k_{4}[\mathrm{MPO}-\mathrm{I}]\left[\mathrm{H}_{2} \mathrm{O}_{2}\right]
\end{aligned}
$$

All Eqs.5-9 contain an unstable MPO-I intermediate. Thus the rate of consumption of MPO-I intermediate can be obtained from the use of steady-state method as follows:

$$
\begin{gathered}
-\frac{\mathrm{d}[\mathrm{MPO}-\mathrm{I}]}{\mathrm{d} t}=-k_{1}[\mathrm{MPO}]\left[\mathrm{H}_{2} \mathrm{O}_{2}\right]+k_{2}[\mathrm{MPO}-\mathrm{I}]\left[\mathrm{Cl}^{-}\right] \\
+k_{3}[\mathrm{MPO}-\mathrm{I}]\left[\mathrm{NO}_{2}^{-}\right]+k_{4}[\mathrm{MPO}-\mathrm{I}]\left[\mathrm{H}_{2} \mathrm{O}_{2}\right]=0
\end{gathered}
$$

Then

$$
[\mathrm{MPO}-\mathrm{I}]=\frac{k_{1}[\mathrm{MPO}]\left[\mathrm{H}_{2} \mathrm{O}_{2}\right]}{k_{2}\left[\mathrm{Cl}^{-}\right]+k_{3}\left[\mathrm{NO}_{2}^{-}\right]+k_{4}\left[\mathrm{H}_{2} \mathrm{O}_{2}\right]}
$$

Pre-steady states studies reported that $k_{4}$ is much smaller than $k_{2}$ and $k_{3}$ [17] and thus reaction 4 is very slow with respect to reactions 1,2 and 3 respectively, then $k_{4}\left[\mathrm{H}_{2} \mathrm{O}_{2}\right]$ could be neglected and omitted from denominator and thus, Eq.11 becomes:

$$
[\mathrm{MPO}-\mathrm{I}]=\frac{k_{1}[\mathrm{MPO}]\left[\mathrm{H}_{2} \mathrm{O}_{2}\right]}{k_{2}\left[\mathrm{Cl}^{-}\right]+k_{3}\left[\mathrm{NO}_{2}^{-}\right]}
$$

The reaction could be studied by monitoring the rate of consumption of $\mathrm{H}_{2} \mathrm{O}_{2}$ and/or the rate of formation of MPO-II. In our case we were able to experimentally 
monitor the rate of consumption of $\mathrm{H}_{2} \mathrm{O}_{2}$. Thus, substitution of Eq.12 in Eq.5 yields the net rate of consumption of $\mathrm{H}_{2} \mathrm{O}_{2}$ through the entire reaction:

$$
-\frac{\mathrm{d}\left[\mathrm{H}_{2} \mathrm{O}_{2}\right]}{\mathrm{d} t}=\underbrace{k_{1}[\mathrm{MPO}]\left[\mathrm{H}_{2} \mathrm{O}_{2}\right]}_{\text {First part }}+\underbrace{\frac{k_{4} k_{1}[\mathrm{MPO}]\left[\mathrm{H}_{2} \mathrm{O}_{2}\right]^{2}}{k_{2}\left[\mathrm{Cl}^{-}\right]+k_{3}\left[\mathrm{NO}_{2}^{-}\right]}}_{\text {Second part }}
$$

Eq.13 illustrates the rate change of consumption of $\mathrm{H}_{2} \mathrm{O}_{2}$ through time scale. At the very early time of reaction (first $10 \mathrm{~s}$ ) fast drop of $\mathrm{H}_{2} \mathrm{O}_{2}$ signal was observed (first phase), indicating domination of first part which is attributed to no significant formation of MPO-II (enzyme is swinging between MPO-1 and ground state MPO). Afterwards, and with presence of increasing concentrations of $\mathrm{NO}_{2}^{-}$, part of MPO-I is reduced to MPO-II causing the enzyme to work under partial activity (second phase) indicating domination of second part of Eq.13.

Consequently, at the early time of the reaction, the rate of consumption of $\mathrm{H}_{2} \mathrm{O}_{2}$ depends only on the first part which is a second order reaction that depends entirely on initial concentrations of MPO and $\mathrm{H}_{2} \mathrm{O}_{2}$ and conclusively, the rate constant $\left(k_{1}\right)$ could be estimated from slope of curve.

$$
-\frac{\mathrm{d}\left[\mathrm{H}_{2} \mathrm{O}_{2}\right]}{\mathrm{d} t}=k_{1}[\mathrm{MPO}]\left[\mathrm{H}_{2} \mathrm{O}_{2}\right]
$$

After the passage of few seconds (10 s), second phase is dominated and $\mathrm{H}_{2} \mathrm{O}_{2}$ consumption will follow the second part of Eq.13 which is observed as exponential decay of $\mathrm{H}_{2} \mathrm{O}_{2}$ signal (Figures 1(b)-(d)). The second part of Eq.13 introduces new variables such as $\left[\mathrm{Cl}^{-}\right]$, $\left[\mathrm{NO}_{2}^{-}\right]$together with [MPO], $\left[\mathrm{H}_{2} \mathrm{O}_{2}\right]$ and rate constant values $k_{1}, k_{2}, k_{3}$ and $k_{4}$, that affect the rate of consumption of $\mathrm{H}_{2} \mathrm{O}_{2}$. Collectively, Eq.13 expresses a two-step sequential decay of $\mathrm{H}_{2} \mathrm{O}_{2}$ signal.

By applying extreme values for $\mathrm{NO}_{2}^{-}$concentration in Eq.13 assuming that $\left[\mathrm{NO}_{2}^{-}\right]=\infty$, then [MPO] approaches [MPO-II] and the rate of consumption of $\mathrm{H}_{2} \mathrm{O}_{2}$ will be zero indicating complete inhibition of reaction 2 . Additionally if $\left[\mathrm{NO}_{2}^{-}\right]=0$ then $k_{3}\left[\mathrm{NO}_{2}^{-}\right]=0$, and Eq.13 could still be used even in the absence of $\mathrm{NO}_{2}^{-}$ions. Biphasic plots were observed for $\left[\mathrm{Cl}^{-}\right]<20 \mathrm{mM}$ (data not shown). This confirms the solidarity and consistency of Eq.13 to present the rate of consumption of $\mathrm{H}_{2} \mathrm{O}_{2}$ in the presence of $\mathrm{MPO}, \mathrm{Cl}^{-}$and presence or absence of $\mathrm{NO}_{2}^{-}$.

Furthermore Eq.13 is a separable differential equation, which can re-write as:

$$
-\frac{\mathrm{d}\left[\mathrm{H}_{2} \mathrm{O}_{2}\right]}{\mathrm{d} t}=A\left[\mathrm{H}_{2} \mathrm{O}_{2}\right]+B\left[\mathrm{H}_{2} \mathrm{O}_{2}\right]^{2}
$$

where $A$ and $B$ are constants, $A=k_{1}[\mathrm{MPO}]$ and $B=\frac{k_{4} k_{1}[\mathrm{MPO}]}{k_{2}\left[\mathrm{Cl}^{-}\right]+k_{3}\left[\mathrm{NO}_{2}^{-}\right]}$. This differential equation can be solved by having different $-\frac{\mathrm{d}\left[\mathrm{H}_{2} \mathrm{O}_{2}\right]}{\mathrm{d} t}$ and $\left[\mathrm{H}_{2} \mathrm{O}_{2}\right]$ values at increasing time and then by using ordinary differential computer program namely Mathematica, $A$ and $B$ values could be determined. The negative $B$ value explains the decrease in the overall rate of consumption of $\mathrm{H}_{2} \mathrm{O}_{2}$ at prolonged time. This finding strengthen the discussion of the solidarity of Eq.13 to present the situation, because it simply states that the second part of Eq.13 is the parameter responsible for the altering $\mathrm{H}_{2} \mathrm{O}_{2}$ consumption from a rapid step to a slower step. Finally, calculated $B$ values were used to estimate the ratio of rate constants $\frac{k_{2}}{k_{3}}, \frac{k_{4}}{k_{3}}$ and $\frac{k_{4}}{k_{2}}$ values. Rate constant ratios are important, because they show the competitiveness of $\mathrm{Cl}^{-}$and $\mathrm{NO}_{2}^{-}$towards reaction with MPO-I, and further explain the slowness of reaction 4 relative to reactions 2 and 3 .

Table 1 and Figure 3 show the change of $k_{1}$ values, deduced from Eq.14 with respect to changes in $\mathrm{Cl}^{-}$ concentrations.

Furthermore, Table 2 and Figure 4 show the change of $k_{1}$ value, deduced from Eq.14 with respect to changes in $\mathrm{NO}_{2}^{-}$concentrations.

After the passage of $10 \mathrm{~s}, \mathrm{H}_{2} \mathrm{O}_{2}$ consumption pattern changes entirely, where the second part of Eq.13 became the major factor. This factor introduces new parameters that affect the rate of consumption of $\mathrm{H}_{2} \mathrm{O}_{2}$ such as $\mathrm{Cl}^{-}$, $\mathrm{NO}_{2}^{-}$and reaction 4 .

Mathematical salvation of Eq.15 at variant consumption rates of $\mathrm{H}_{2} \mathrm{O}_{2}$ versus $\mathrm{H}_{2} \mathrm{O}_{2}$ concentrations under variant chloride and nitrite concentrations (i.e. Tables 1 and 2) yielded $A$ and $B$ constant values, and consequently the determined B constant values were employed to estimate $\frac{k_{4}}{k_{3}}, \frac{k_{4}}{k_{2}}$ and $\frac{k_{2}}{k_{3}}$ ratios (Table 3 ).

Rate constant ratios tell explicitly which reaction is faster or slower in the mechanism, and hence several conclusive remarks could be concluded from Table 3 . Firstly, is that $k_{3}$ is much larger than $k_{2}$, which emphasizes that the nitrite inhibition reaction 3 producing MPO-II, is faster than the catalyzing reaction 2 producing $\mathrm{HOCl}$, (i.e. $\frac{k_{2}}{k_{3}}=1.15 \times 10^{-3}$ ), and that confirms the inhibition nature of $\mathrm{NO}_{2}^{-}$in the mechanism.

Secondly, the previously assumed that $k_{3} \gg k_{4}$ has been mathematically justified and it was also proven that $k_{4}$ is very much smaller than $k_{3}$ or $k_{2}$. Finally, reaction 4 
Table 1. Change of rate constant $\left(k_{1}\right)$ versus chloride ion concentration $\left[\mathrm{Cl}^{-}\right]$.

\begin{tabular}{cc}
\hline$k_{1}\left(\mathrm{M}^{-1} \cdot \mathrm{s}^{-1}\right)$ & {$\left[\mathrm{Cl}^{-}\right], \mathrm{mM}$} \\
\hline $2.33 \times 10^{5}$ & 5 \\
$2.67 \times 10^{5}$ & 10 \\
$3.02 \times 10^{5}$ & 25 \\
$3.96 \times 10^{5}$ & 50 \\
$5.23 \times 10^{5}$ & 100 \\
\hline
\end{tabular}

$[\mathrm{MPO}]=50 \mathrm{nM},\left[\mathrm{H}_{2} \mathrm{O}_{2}\right]=10 \mu \mathrm{M},\left[\mathrm{NO}_{2}^{-}\right]=100 \mu \mathrm{M}$, in $100 \mathrm{mM}$ phosphate buffer, $\mathrm{pH}=7.0$, containing $30 \mu \mathrm{M}$ EDTA at $25^{\circ} \mathrm{C}$.

Table 2. Change of rate constant $\left(k_{1}\right)$ versus nitrite ion concentration $\left[\mathrm{NO}_{2}^{-}\right]$.

\begin{tabular}{cc}
\hline$k_{1}\left(\mathrm{M}^{-1} \cdot \mathrm{s}^{-1}\right)$ & {$\left[\mathrm{NO}_{2}^{-}\right], \mu \mathrm{M}$} \\
\hline $1.5 \times 10^{6}$ & 0 \\
$1.4 \times 10^{6}$ & 25 \\
$7.13 \times 10^{5}$ & 50 \\
$5.75 \times 10^{5}$ & 100
\end{tabular}

$[\mathrm{MPO}]=50 \mathrm{nM},\left[\mathrm{H}_{2} \mathrm{O}_{2}\right]=10 \mu \mathrm{M},\left[\mathrm{Cl}^{-}\right]=100 \mathrm{mM}$, in $100 \mathrm{mM}$ phosphate buffer, $\mathrm{pH}=7.0$, containing $30 \mu \mathrm{M}$ EDTA at $25^{\circ} \mathrm{C}$.

Table 3. Rate constant ratios in the presence and absence of $\left(\mathrm{NO}_{2}^{-}\right)$inhibitor.

\begin{tabular}{cccc}
\hline Rate constant ratios & $\frac{k_{2}}{k_{3}}$ & $\frac{k_{4}}{k_{3}}$ & $\frac{k_{4}}{k_{2}}$ \\
\hline $\begin{array}{c}\text { Presence of }\left(\mathrm{NO}_{2}^{-}\right) \\
\text {inhibitor }\end{array}$ & $1.15 \times 10^{-3}$ & $7.0 \times 10^{-8}$ & $6.09 \times 10^{-5}$ \\
$\begin{array}{c}\text { Absence of }\left(\mathrm{NO}_{2}^{-}\right) \\
\text {inhibitor }\end{array}$ & - & - & $4.4 \times 10^{-3}$ \\
\hline
\end{tabular}

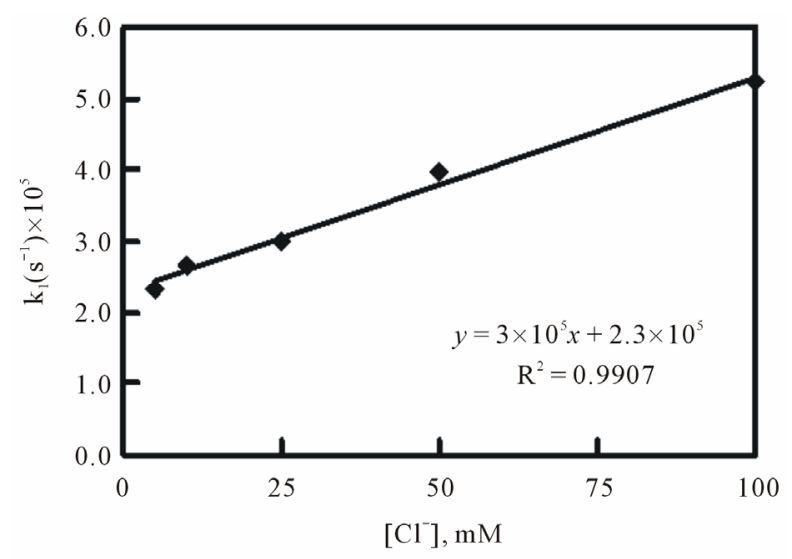

Figure 3. Change of rate constant $\left(k_{1}\right)$ versus chloride ion concentration $\left[\mathrm{Cl}^{-}\right]$.

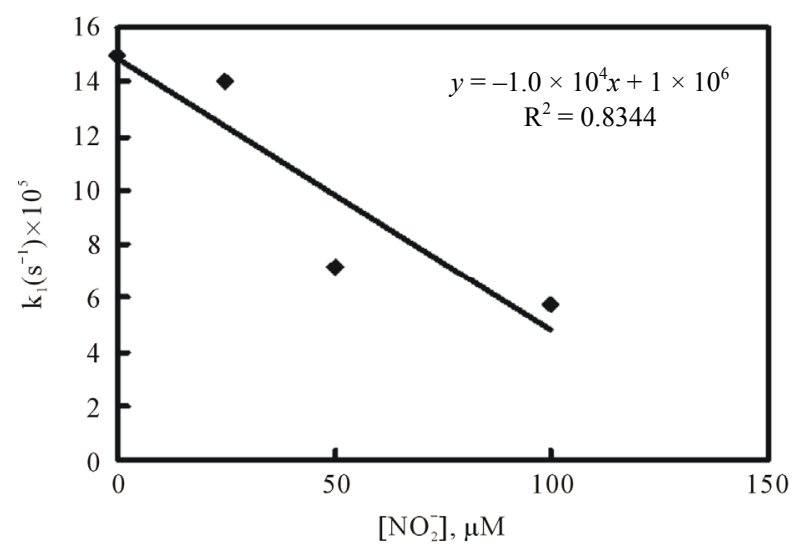

Figure 4. Change of rate constant $\left(k_{1}\right)$ versus nitrite ion concentration $\left[\mathrm{NO}_{2}^{-}\right]$.

becomes significant in absence of $\mathrm{NO}_{2}^{-}$.

\section{CONCLUSIONS}

Assessment of MPO-catalytic activity towards oxidation of chloride and other halides is a complex and multifunctional process $[24,29]$. MPO catalytic activity is dependent on initial concentrations of $\mathrm{MPO}, \mathrm{H}_{2} \mathrm{O}_{2}, \mathrm{Cl}^{-}$, $\mathrm{pH}, \mathrm{H}_{2} \mathrm{O}_{2}$ to MPO concentration ratio and order of mixing. Thus, development of a comprehensive kinetic model is a complex task. We acknowledge that our proposed kinetic model is limited to describing our experimental data.

Proposed kinetic steady-state model was able to explain the monophasic and biphasic phenomena in absence and presence of nitrite. Additionally, the model was able to estimate values for $k_{1}$ and $\frac{k_{4}}{k_{3}}, \frac{k_{4}}{k_{2}}$ and $\frac{k_{2}}{k_{3}}$ rate constant ratios. Interestingly, this model supports previous findings that MPO has two binding sites that have distinct impact on the heme iron microenvironment [29]. Chloride occupied one site as substrate and nitrite occupied the other site as inhibitor.

\section{ACKNOWLEDGEMENTS}

Experimental work was done at Department of Obstetrics and Gynecology, Wayne State University, MI, USA. Principal author would like to thank Prof. Husam Abu-Soud for supplying facilities to conduct this research. Also thanks to Jordan University for Science and Technology for financing a research sabbatical to principal and corresponding author.

\section{REFERENCES}

[1] Mauch, L., Lun, A. and O'Gorman, M.R. (2007) Chronic 
Granulomatous disease (CGD) and complete myeloperoxidase deficiency both yield strongly reduced dihydrorhodamine 123 test signals but can be easily discerned in routine testing for CGD. Clinical Chemistry, 53, 890896. doi:10.1373/clinchem.2006.083444

[2] Heinecke, J.W., Li, W., Francis, G.A. and Goldstein, J.A. (1993) Tyrosyl radical generated by myeloperoxidase catalyzes the oxidative cross-linking of proteins. The Journal of Clinical Investigation, 91, 2866-2872. doi:10.1172/JCI116531

[3] Malle, E., Buch, T. and Grone, H. J. (2003) Meyeloperoxidases in kidney disease. Kidney International, 64, 1956-1967. doi:10.1046/j.1523-1755.2003.00336.x

[4] Exner, M., Hermann, M., Hofbauer, R., Hartmann, B., Kapiotis, S. and Gmeiner, B. (2004) Thiocyanate catalyzes myeloperoxidase-initiated lipid oxidation in LDL. Free Radical Biology \& Medicine, 37, 146-155. doi:10.1016/j.freeradbiomed.2004.04.039

[5] Bergt, C. Marsche, G., Panzenboeck, U., Heinecke, J. W., Malle, E. and Sattler, W. (2001) Human neutrophils employ the myeloperoxidase/hydrogen peroxide/chloride system to oxidatively damage apolipoprotein A-I. European Journal of Biochemistry, 268, 3523-3531. doi:10.1046/j.1432-1327.2001.02253.x

[6] Anderson, M.M., Hazen, S.L., Hsu, F.F. and Heinecke, J.W. (1997) Human neutrophils employ the myeloperoxidase-hydrogen peroxide-chloride system to convert hydroxy-amino acids into glycolaldehyde, 2-hydroxypropanal, and acrolein. The Journal of Clinical Investigation, 99, 424-432. doi:10.1172/JCI119176

[7] Nagai, R., Hayashi, C.M., Xia, L., Takkeya, M. and Horiuchi, S. (2002) Class B scavenger receptors CD36 and SR-BI are receptors for hypochlorite-modified low density lipoprotein. The Journal of Biological Chemistry, 277, 48905-48912. doi:10.1074/ibc.M205688200

[8] Van der Vliet, A., Eiserich, J.P., Halliwell, B. and Cross, C.E. (1997) Formation of reactive nitrogen species during peroxidase-catalyzed oxidation of nitrite. The Journal of Biological Chemistry, 272, 7617-7625. doi:10.1074/jbc.272.12.7617

[9] Eiserich, J.P., Hristova, M., Cross, C.E., Jones, A.D., Freeman, B.A., Halliwell, B. and Van der Vliet, A. (1998) Formation of nitric oxide-derived inflammatory oxidants by myeloperoxidase in neutrophils. Nature, 391, 393-397. doi:10.1038/34923

[10] Sampson, J.B., Ye, Y.Z., Rosen, H. and Beckman, J.S. (1998) Myeloperoxidase and horseradish peroxidase catalyze tyrosine nitration in proteins from nitrite and hydrogen peroxide. Archives of Biochemistry and Biophysics, 356, 207-213. doi:10.1006/abbi.1998.0772

[11] Kettle, A. and Winterbourn, C. (1997) Myeloperoxidase: A key regulator of neutrophil oxidant production. Redox Report, 3, 89-107.

[12] Hurst, J.K. (1991) Peroxidases in chemistry and biology Vol. 1. In: Everse, J., Everse, K. and Grisham, M., Eds., CRC Press, Boca Raton, 37-62.

[13] Burner, U., Furtmuller, P., Kettle, A., Koppenal, W. and Obinger, C. (2000) Mechanism of reaction of myeloperoxidase with nitrite. The Journal of Biological Chemistry, 275, 20597-2060. doi:10.1074/jbc.M000181200

[14] Van Dalen, C., Winterbourn, C., Santhilmohan, R. and Kettle, A. (2000) Nitrite as a substrate and inhibitor of myeloperoxidase, The Journal of Biological Chemistry, 275, 11638-11644. doi:10.1074/jbc.275.16.11638

[15] Kettle, A. and Winterbourn, C. (1994) Assays for the chlorination activity of myeloperoxidase. Methods in Enzymology, 233, 502-512. doi:10.1016/S0076-6879(94)33056-5

[16] Van Dalen, C., Whiterhouse, M., Winterbourne, C. and Kettle, A. (1997) Thiocyanate and chloride as competing substrates for myeloperoxidase. Biochemical Journal, 327, 487-492.

[17] Kettle, A. and Winterbourn, C. (2001) A Kinetic analysis of the catalase activity of myeloperoxidase. Biochemistry, 40, 10204-10212. doi:10.1021/bi010940b

[18] Wang, J. (2005) Carbon nanotube based electrode biosensors: A review. Electroanalysis, 17, 7-14. doi:10.1002/elan.200403113

[19] World Precision Instruments. www.wpiinc.com

[20] Tahboub, Y. and Abu-Soud, H. (2010) Steady-state study of inhibitory effect of nitrite on meyeloperoxidase catalytic activity by hydrogen peroxide biosensor. Portugaliae Electrochimica Acta, 28, 27-38. doi:10.4152/pea.201001027

[21] Rakita, R., Michel, R. and Rosen, H. (1990) Differential inactivation of Escherichia coli membrane dehydrogenases by a myeloperoxidase-mediated antimicrobial system. Biochemistry, 29, 1075-1080. doi:10.1021/bi00456a033

[22] Wever, R., Plat, H. and Hamers, M. (1981) Human eosinophil peroxidase: A novel isolation procedure, spectral properties and chlorinating activity. Human eosinophil peroxidase: A novel isolation procedure, spectral properties and chlorinating activity. FEBS Letters, 123, 327-333. doi:10.1016/0014-5793(81)80320-1

[23] Agner, K. (1963) Studies on myeloperoxidase activity. Acta Chemica Scandinavica, 17, S332-S338. doi:10.3891/acta.chem.scand.17s-0332

[24] Tahboub, Y.R., Galijasevic, S., Diamond M.P. and AbuSoud, H.M. (2005) Thiocyanate modulates the catalytic activity of mammalian peroxidases. The Journal of Biological Chemistry, 280, 26129-26136. doi:10.1074/jbc.M503027200

[25] Floris, R., Piersma, S.R., Yang, G., Jones, P. and Wever, R. (1993) Interaction of myeloperoxidase with peroxynitrite. European Journal of Biochemistry, 215, 767-775. doi:10.1111/j.1432-1033.1993.tb18091.x

[26] Furtmüller, P.G., Burner, U. and Obinger, C. (1998) Reaction of myeloperoxidase compound I with chloride, bromide, iodide, and thiocyanate. Biochemistry, 37, 17923-17930.

[27] Galijasevic, S., Abdulhamid, I. and Abu-Soud, H.M. (2008) Potential role of tryptophan and chloride in the inhibition of human myeloperoxidase. Biochemistry, 47, 2668-2677. doi:10.1021/bi702016q

[28] Ashby, M.T., Carlson, A.C. and Scott, M.J. (2004) Redox buffering of hypochlorous acid by thiocyanate in physiologic fluids. Journal of the American Chemical Society, 126, 15976-15977. doi:10.1021/ja0438361

[29] Proteasa, G., Tahboub, Y., Galijasevic, S., Russel, F. and Abu-Soud, H. (2007) kinetic evidence supports the existence of two halide binding sites that have a distinct impact on the heme microenvironment of myeloperoxidase Biochemistry, 46, 398-405. doi:10.1021/bi0609725 